\author{
Albina M. Milanov \\ Filozofski fakultet - doktorske studije Metodike nastave, Novi Sad \\ albinamilanov@yahoo.com
}

\title{
BULGAKOV U NASTAVNOJ PRAKSI
}

\begin{abstract}
Apstrakt
U tekstu koji sledi prikazani su rezultati mikroistraživanja sprovedenog u gimnaziji „Jovan Jovanović Zmaj“ u Novom Sadu marta meseca tekuće godine ${ }^{1}$. Istraživački projekat podrazumeva praćenje nastavne jedinice koja se izvodi inovativnim metodama, posebno izrađenim i osmišljenim u skladu sa kulturološkim pristupom u proučavanju književnosti. Pretpostavka od koje autor polazi je da motivisanost učenika za čitanje i promišljanje teksta direktno zavisi od pristupa koji se primenjuje u obradi dela u nastavi, kao i od metode koja se primenjuje u nastavnom procesu. Projekat obuhvata obradu nastavne jedinice odabranim metodama, uz posebno kreirane pripreme, posmatranje učenika tokom nastave i analizu evaluacionih listića koje popunjavaju učenici anonimno i evaluacionog listića koji popunjava nastavnik. Zaključak u velikoj meri potvrđuje hipotezu, uz napomenu da se uslovi u kojima je obavljeno istraživanje donekle mogu smatrati idealnim.
\end{abstract}

Ključne reči: intertekstualnost, istraživanje, motivacija, nastava.

\section{UVOD}

Nastavna praksa društveno-humanističkih predmeta suočena je sa nekolicinom problema koje sa sobom nose tempo i način života današnjice. Dostupnost informacija putem interneta i drugih medija kod učenika stvara utisak redundantnosti i pojačava demotivaciju za učešćem u nastavi. Svedoci smo fenomena krize čitanja kod dece školskog uzrasta, srednjoškolaca i omladine ${ }^{2}$, tako da ne iznenađuje pomenuti odnos prema predmetu, naročito kada je u pitanju nastava književnosti. Primećujemo, takođe, da i pred dostupnosti i obilnosti informacija, učenici nemaju razvijen kritički stav prema njima i nisu uvek sposobni da procene

1 Ovim putem se zahvaljujem prof. gimnazije Rimi Lakić na saradnji, izuzetnoj kolegijalnosti, savesnosti i entuzijazmu, uz osvrt na njen vanserijski talenat za nastavnu praksu. Zahvalnost dugujem i direktoru Radivoju Stojkoviću na saglasnosti i dozvoli za obavljeno istraživanje.

2 Više o ovom problemu vidi studiju P. Ilića, O. Gajić i M. Maljković (Ilić et.al. 2008). 
verodostojnost $\mathrm{i}$ ispravnost izvora, kao ni da ih potraže na pravom mestu i na pravi način. Uloga nastavnika danas nije više da određenu informaciju učeniku plasira, već da ga nauči i osposobi kako da do nje sam dođe, te da stečeno znanje na adekvatan način sistematizuje, kako bi ono imalo trajnost i operativnost.

U tom smislu, uloga profesora književnosti danas nije da očekuje od učenika da dođe do željenih zaključaka čitajući određeno delo, već da ga motiviše na samostalno čitanje, promišljanje i istraživanje, na povezivanje sa drugim književnim delima i saznanjima stečenim na časovima drugih društveno-humanističkih predmeta i da ga podstakne na formiranje i izlaganje ličnih stavova prema usvojenom sadržaju. S tim u vezi autor smatra da je nužno da profesor književnosti u kreiranju svojih časova poštuje tekovine savremene književnoteorijske metodologije, jer idući u korak sa naukom predmeta koji predaje zapravo ide u korak sa društvom, i samo na taj način formirana nastava datog predmeta može da obavi svoje primarne ciljeve: da vaspita i obrazuje mladog intelektualca, pripremajući ga za ulogu člana društvene zajednice u kojoj živi i stvara.

U tekstu koji sledi autor izlaže pristup problemu, moguća teorijska rešenja i rezultate istraživačke prakse koja podrazumeva primenu jednog od njih na odabranom uzorku. Budući da se u nekim ranije publikovanim radovima autora već govorilo o ideji primene kulturološkog pristupa i komparativnog metoda uopšte na nastavnu praksu, uz korišćenje prilagođenih nastavnih metoda u okviru korelacijsko-integracijskog metodičkog sistema i problemske nastave, u ovom će se napraviti samo kraći osvrt na tu temu kako bi se kontekstualizovalo istraživanje o kojem će biti reči.

\section{MOTIVACIJA, INTERTEKSTUALNOST I NASTAVA}

Stručnjaci iz oblasti bihevioralističke psihologije u svojim istraživanjima najviše pažnje posvećuju motivaciji, jer ona leži u osnovi svake akcije u svojstvu pokretača. Pedagoška psihologija, takođe, ističe njenu važnost, jer je prepoznaje kao jedan od ključnih faktora koji utiču na uspešnost saznajnog procesa. Proučavaoci ovih oblasti raščlanjuju motivaciju na četiri koncepcije: jednostruke, dvostruke i višestruke motivisanosti i koncepciju hijerarhije motiva (Gage - Berliner 1998: 317-318). Koncepcija jednostrukog motiva podrazumeva, dakako, jedan ustremljujući motiv i kao primer navodi se Frojdovo tumačenje libida; koncepcija dvostrukog motiva zagovara princip polariteta, odnosno, da jedinka svoje delovanje usmerava na osnovu sučeljavanja dveju suprotstavljenih strana, kao što su npr. dobro i zlo; koncepcija višestrukih motiva ponašanje jedinke objašnjava kao rezultat uticaja mnogobrojnih motiva, ponekad i istovremeno, od kojih autori 
navode, na primer, želju za dostignućima, moći, igrom, afilijacijom itd. Najkompleksnija je koncepcija hijerarhije motiva, koja takođe zagovara brojnost motiva koji upravljaju ljudskim ponašanjem, ali ističe da među njima postoji hijerarhija, jer zadovoljenje jednih utiče na aktivaciju drugih. Autori se rukovode Maslovljevom hijerarhijom motiva (Gage - Berliner 1998: 318 prema: Maslow 1954) koji su postavljeni u pet osnovnih nivoa i idu od zadovoljavanja osnovnih fizičkih, preko društvenih, intelektualnih i estetskih potreba do čiste samorealizacije, odnosno, motivisanja jedinke samim postankom onime što jeste. Međusobno se, takođe, mogu podeliti u dve grupe, pa tako u prvu grupu spadaju prva dva nivoa motiva koji zavise od spoljašnjih faktora, veoma su snažnog uticaja i jačaju što im je zadovoljenje uskraćenije, za razliku od preostala tri, koja spadaju u drugu grupu i zavise od unutrašnjih faktora, suptilnijeg su uticaja i jačaju zadovoljavanjem. Ukoliko se primarni motivi zadovolje, jedinka teži da dostigne zadovoljenje sekundarne motivacije, koja, dakle, podrazumeva ispunjavanje želje za ličnim dostignućima, želje za saznanjem i razumevanjem, kao i da se u svemu vidi harmonija, lepota i ljubav, do konačne samorealizacije u kojoj je jedinka motivisana svojim ostvarenjem kao kompletne etičke, estetske, autonomne, kreativne i društveno prihvaćene ličnosti. Ova kategorizacija motiva nam je izuzetno važna jer upravo ističe da svaka osoba teži samorealizaciji do koje se dolazi zadovoljavanjem intelektualnih potreba. Naročito je za nastavnike važna motivacija za saznanjem i ličnim dostignućima, jer ona direktno utiče na saznajni proces.

Pitanjem motivacije u nastavnom procesu autor se bavi i u svom radu Inovativnost u nastavnom procesu kao put ka motivisanom učeniku (Milanov 2013). Ovde ćemo se samo ukratko osvrnuti na neke od činjenica već istaknutih u tom tekstu, kako bismo postavili okvir istraživanju o kojem će biti reči. Dakle, pedagoška psihologija ukazuje na to da postoji nekoliko faktora u nastavnom procesu, međusobno povezanih i zavisnih, koji utiču na motivaciju učenika. Svakako je na prvom mestu materija kojom se predmet bavi jer je ona u direktnoj vezi sa samom ličnošću učenika. Svako od nas ima prirodnih afiniteta ka nečemu i rad će biti motivisaniji ukoliko se osoba bavi materijom koja ga emotivno, intelektualno i estetski ispunjava. Ocena je svakako jedan od jačih motivatora jer se, pored nagrade koja učeniku obično kod kuće sleduje, u zavisnosti od kriterijuma postavljenih u učionici formira i konkurencija među učenicima koja direktno uslovljava motivisanost, a videli smo da ovakav tip motivacije spada u drugu grupu hijerarhijskih motiva i po snazi je ekvivalentna motivu za opstanak. Zatim, jedan od motivatora su i metodički modeli i pristupi sadržaju časova, odnosno, način prezentacije građe u nastavi, i mahom zavise od metodologije nauke datog predmeta, dok metodički modeli uglavnom zavise od odabranog pristupa, ali i koncepcije udžbenika i drugih nastavnih sredstava. Odabirom adekvatnog pristupa i metodičkog modela 
nastavnik u velikoj meri doprinosi motivisanosti učenika, gotovo jednako koliko i samom svojom ličnošću i sopstvenom motivisanošću. Stoga su ličnost nastavnika i njegova motivacija možda i najvažniji od svih faktora koji utiču na motivisanost učenika. Nastavnik predstavlja direktnu sponu između učenika i predmeta, a sve ostalo su samo sredstva kojima se služi kako bi se izgradila konstrukcija znanja.

Ličnost nastavnika književnosti, njegov senzibilitet i motivisanost spram materije koju predaje imaju presudan značaj. Od toga zavisi kakav će analitičko-interpretativni metod nastavnik odabrati, kojim sredstvima će kreirati nastavu, a znamo da je nastava književnosti jednako čin kreacije koliko i samo čitanje dela. Predavanje književnosti tradicionalnim modelima se mahom svodi na ponavljanje - postoji uvrežena interpretacija dela i poruka koja se iz dela iščitava, tako da zadatak nastavnika nije nimalo zahtevan jer okoštalom analizom, iz godine u godinu, očekuje istovetne odgovore i zaključke od učenika. Ova ,utabana staza" kojom se ide je pogubna za motivaciju samog nastavnika na prvom mestu, što se prenosi i na učenike, i na kraju rezultira obostranom nezainteresovanošću za predmet i robotizovanom izvršavanju zadataka. Ukoliko nastavnik, međutim, prati naučno-metodološke književnoteorijske tokove i svoja čitanja, analize i interpretacije teksta zasniva na njima, i, konačno, tome prilagodi i nastavu, dolazi do lančane reakcije koja bi potencijalno mogla voditi rešavanju problema krize čitanja. Naime, nauka o književnosti od sredine prošlog veka u svetu zajedno sa društveno-humanističkim naukama teži formiranju tzv. cultural studies, tj. kulturoloških studija. Gledajući na književnost kao na jedan od kulturoloških fenomena i fundamenata obrazovanja, a pritom se koristeći komparativnom metodom prilikom analize i interpretacije teksta, interdisciplinarnost kojom se na taj način prilazi delu otvara nastavniku brojne mogućnosti za kreiranje posve originalne i savremene nastave.

Budući da „novo vreme“ traži nove pisce i nove čitaoce, logično je očekivati da traži i nove nastavnike. Postmodernistička poetika nije promenila samo pogled na novostvorenu književnost, već i na čitavo ljudsko stvaralaštvo. Tako sva dela, sve što je rečju ikad napisano ili stvoreno kao artefakt, pored toga što je predmet preispitivanja i reinterpretacije kao građa za nove tekstove, postaje i predmet dekonstrukcije sa čitalačkog aspekta. Ovaj fenomen je definisala Julija Kristeva terminom intertekstualnost ${ }^{3}$ koji, grubo rečeno, označava međusobni dijalog tekstova, slično Bahtinovom stavu da reči svoje puno značenje oslobađaju tek u relaciji sa drugim rečima (Bahtin 1989). Na osnovu ovih stavova možemo reći da pojedinačni tekstovi svoje pune značenjske potencijale oslobađaju tek kada ih dovedemo u vezu sa nekim drugim tekstom. Ove veze se ostvaruju putem citata i aluzija, u koje mogu spadati svi elementi književnog dela, od naslova,

3 Za sve u vezi sa pojmom intertekstualnosti vidi detaljnu studiju Marka Juvana (Juvan 2013). 
podnaslova, žanrovskih odrednica, strukture do motiva, tema, imena junaka itd. Postavljajući delo u ovakvu perspektivu mogućnosti interpretacija su nebrojene i zavise isključivo od književne kulture i kompetencije čitaoca, a kako je učenička dakako siromašnija od nastavničke, on im predstavlja oslonac i smernicu za pravilno čitanje i kontekstualizovanje dela koja se na času obrađuju.

U tom smislu, dakle, i nastava podleže ,postmodernizaciji“ jer osveženom pristupu tekstu moramo prilagoditi i nastavne metode. Postmoderna poetika legitimiše reinterpretaciju teksta drugim tekstom, dok semiotika (kroz Lotmanov pojam semiosfere (Lotman 2004) kao semiotičkog prostora date kulture u okviru kojeg se presecaju različiti jezički sistemi koji su njen sastavni deo) legitimiše reinterpretaciju i tumačenje književnosti (kao kulturološkog fenomena i jezičkog sistema) nekim drugim jezičkim sistemom iz polja semiosfere date kulture (muzika, slikarstvo, film itd.). Dakle, ako književnost posmatramo kao kulturološki fenomen i fundament obrazovanja, koja za potrebe interpretacije podrazumeva i znanja iz oblasti društveno-humanističkih nauka i umetnosti, onda u nastavi možemo sasvim legitimno (čak bi to bilo i poželjno) ohrabriti učenike da se služe znanjem stečenim na časovima tih predmeta. Učenici treba da koriste sva znanja koja poseduju, da uočavaju sve moguće veze između dela koje analiziraju na času i ostvarenja koja pripadaju drugim umetnostima, kao što su film, strip, video-igrice i tome slično, polazeći od toga da svi ti sadržaji počivaju na nekoj vrsti tekstualne građe. Na taj način nastavnik čitavu književnu baštinu ili Borhesovu Vavilonsku biblioteku učenicima predstavlja kao tvorevinu nalik na internet, gde bi uočavanje intertekstualnih smernica bilo poput praćenja linkova, a zaustavljanje kod svake smernice otvaralo stranice i stranice novih sadržaja. Približavanje pojma i koncepta književnosti kroz metaforu interneta je način da se učenicima „osavremeni““ i osveži pogled na fenomen koji njima danas, u svetu tehnologije u kom živimo, deluje prilično zastarelo, dok bi funkcionalni i obrazovni ciljevi ovakvog pristupa bili orijentisani na osposobljavanje učenika za samostalan istraživački rad.

\section{BULGAKOV U SVETLU NOVIH METODA}

Bulgakovljev roman Majstor i Margarita nalazi se u programu lektira za IV razred gimnazija. Usled kompleksnosti samog dela, učenici imaju problem da ga adekvatno pročitaju i razumeju, što vodi negativnom stavu prema tekstu. O ovom romanu postoji brojna literatura kako domaćih tako i stranih autora, i premda sva ta iščitavanja i analiziranja zahtevaju napor i vreme, profesori književnosti prenebregavaju činjenicu da, koristeći se komparativnim metodom i intertekstualnošću kao načinom interpretacije, mogu u velikoj meri sažeti obimnu građu, i, umesto 
da analiziraju detalje pojedinačnih romana, zapravo reinterpretiraju svaki od njih uočavajući i prateći ključne motive koji se u svim tim delima ponavljaju, kao i žanrovske odrednice, moto, naslove i sl.

Tradicionalan pristup obradi ovog romana na času podrazumeva šablon koji se primenjuje kod analize i interpretacije većine književnih dela: biobibliografski podaci o piscu, bibliografski podaci o samom romanu, osvrt na strukturu dela, uočavanje teme i motiva, analiza likova, te sinteza i isticanje idejne suštine. Kad se ovaj šablon popuni podacima o konkretnoj nastavnoj jedinici to bi izgledalo otprilike ovako: život i delo Mihaila Bulgakova i njegova poetika koja je iskrojena tim životnim putem (Ipolit Ten i ,rasa, sredina, trenutak“ kao opšte mesto književne analize); vreme u kome ovaj roman nastaje i vreme kad je objavljen kao anahronizam u svakom smislu; struktura podrazumeva roman u romanu - priča o Volandu i Majstoru unutar koje je priča o Pontiju Pilatu; tema je kritika Staljinovog režima u Rusiji, odnosno, suđenje Ješui Ha-Nocriju; ideja romana se sintetiše oko Volandove konstatacije da rukopisi ne gore.

Analiza ovog romana je, ipak, veoma zahtevna, jer mimo romana o Pontiju Pilatu, koji je potrebno posebno analizirati, roman o događajima u Moskvi ima paralelni sklop i u završnim poglavljima se na neki način preklapaju, što uz brojne fantastične epizode, promene imena junaka i parodične tirade čini ovaj roman veoma zahtevnim čak i za veštijeg čitaoca. Stoga je ideja ovog istraživanja bila da se kulturološkom i komparativnom analizom osavremeni pogled na ovaj tekst, $i$ da se $u$ tom smislu ugao njegove prezentacije i analize u nastavi postavi tako da se učenici na ovom primeru osposobe da čitaju ovakvu vrstu literature. Naime, osnovna analitičko-interpretativna pozicija u odnosu na ovo delo bi bila da ga posmatramo kao postmodernistički, ,semiotički“ roman, odnosno tekst koji pisac namerno „kodira“ i koji obiluje intertekstualnom ironijom. Njime možemo imenovati sve tekstove u kojima pisac prijateljski namiguje čitaocu, kako to Umberto Eko naziva, objašnjavajući ovakve književne forme kao tekstove koje mogu s uživanjem da čitaju i neupućeni čitaoci, a da pri tom ne shvate intertekstualne navode, ali i oni upućeniji, koji potpuno svesno kreću u lov na njih (Eko 2011: 270). Dakle, zadržao bi se uvodni deo koji podrazumeva kontekstualizovanje pisca i dela u vremenu i prostoru, s tim što bi se skrenula pažnja na to da će objašnjenje pozicije tumačenja dela iz ugla poetike postmoderne, a s obzirom na anahronizme u vezi sa pisanjem i objavljivanjem romana, uslediti nakon njegove interpretacije. Pored sporadičnih iznošenja činjenica monološki, nastava se u suštini zasniva na heurističkom dijalogu, uz praćenje ključnih tačaka zapisivanjem na tablu ili koncipiranjem razgovora oko teza izloženih PP prezentacijom (u zavisnosti od opremljenosti kabineta). U vezi sa romanom o Pontiju Pilatu, ili kako ga kritika naziva (ugledajući se na moguće naslove koje je sam pisac dao delu, pa kasnije odbacio) 
Jevanđelje po Volandu ili Jevanđelje po Bulgakovu, na jednom od časova je predviđeno pustiti inserte iz dokumentarnih filmova Riddles of the Bible - Dead Sea Scrolls (Zagonetke Biblije - Svici s Mrtvog mora) i The Real Da Vinci Code (Istiniti Da Vinčijev kod) koji se bave Biblijom kao kulturološkim fenomenom. Inserti iz dokumentarnih filmova nam ukazuju na pronalazak pomenutih svitaka, poznatih još i pod nazivom Kumranski spisi, govore nam o tome šta oni podrazumevaju, kako na njih gleda nauka danas i koliko je uspela da ih rekonstruiše i verifikuje. ${ }^{4}$

Da bismo izbegli haotičnost i svojoj analizi Majstora i Margarite dali okvir i putanju, nećemo sasvim odbaciti njene klasične aspekte, već ćemo im dati novo svetlo posmatrajući tri sloja u romanu: prvi sloj bi bio satira, drugi bi bio fantastika, a treći koji bismo istakli bi bio onaj ključan - dekonstrukcija, i njega bismo ostavili za poslednji čas, kao zaključak. Kroz slojeve satire i fantastike ćemo proći fabulu romana i pobrojati motive, a na trećem času ćemo, uz razgovor o dekonstrukciji, te motive umrežiti. Ono na šta ciljamo kao književni mit koji ćemo pratiti i koji nam je okosnica tumačenja je svakako Faust i arhetip čoveka sumnje (u koji jednako spadaju i Majstor i Pilat). Istaći ćemo na koji način je pomenuti mit ovde transponovan. Pomenućemo, svakako, veštičarenje i orgijastičke svečanosti kao kulturološki momenat koji se vezuje i za Eleusinske misterije i nastanak tragedije, odnosno, koren svega umetničkog jer je umetnost nastala iz magije. Sa druge strane, imamo ideju veze između stvaranja i ludila, da umetnost nastaje $u$ transu i plaća se životom. To je ona ideja grčkog agona, uzvišene borbe kako bismo pobedili sebe (Majstor), tj. (post)moderna ideja da je stvaranje agonija, da je stvaranje pakt sa đavolom i da reči traže glavu, kao i da u savremenoj umetnosti ta ideja da rukopisi ne gore ima oblik pakta sa đavolom koji se potpisuje krvlju (te se stoga dokument ne može uništiti).

Sa tim je opet u direktnoj vezi i aktuelnost romana danas, tj. Bulgakovljeva neosporna vizionarnost, jer on u trenutku u kom piše potpuno borhesovski gleda na literaturu i pisanje, ostavlja čak i bibliografiju i piše sopstveno jevanđelje. I pored satiričnih razloga, ovaj potez se savršeno može dovesti u vezu sa problematikom koja muči postmoderne autore, a to je autentičnost i vrednost dokumenta, njihov odnos prema istoriji i validnosti činjenica koje se neprekidno preispituju, jer je suština postmoderne ne isticati ono što znaš, već neprekidno preispitivati to svoje znanje. Sa druge strane, stoji ideja da se otkrićem svitaka sa Mrtvog mora dodatno poljuljalo postolje na kojem stoji Biblija kao izvor vere, što je u Rusiji već učinjeno

4 Pomenuti dokumentarni filmovi se mogu pronaći onlajn u celosti, i na kraju ovog teksta dati su linkovi ka njihovoj internet adresi, sa istaknutom minutažom svakog inserta koji je predviđen za puštanje. Ukoliko u učionici ne postoji internet konekcija, filmove je moguće, uz pomoć specijalnih programa, sačuvati na DVD-u ili nekoj drugoj vrsti spoljne memorije, pa pustiti na času, ukoliko za to postoje uslovi. 
režimskim promenama decenijama ranije, što od sedamdesetih pa na ovamo ovaj roman čini izuzetno aktuelnim. Ovo poslednje objašnjava pomenuti anahronizam romana: u godinama kada je pisan (u periodu uzmeđu 1928. i 1940. godine) on anticipira postmodernističku poetiku, a sudbina je htela da bude objavljen u trenutku kada ta poetika doživljava ekspanziju popularnosti među piscima i publikom (1966. je objavljivan u nastavcima, 1967. prvi put kao jedinstven tekst ali sa cenzurama, 1973. je objavljena prva necenzurisana verzija koja se bazira na rukopisu iz 1940, a tek 1989. konačna verzija bazirana na svim dostupnim rukopisima). „Jevanđelje“ koje Bulgakov piše, problematizujući tekst Biblije, predstavlja tipološku analogiju par ekselans jer apokrifna jevanđelja bivaju pronalažena u periodu između 1947. i 1956. godine, dakle tokom petnaest godina nakon njegove smrti.

\section{METODE, TEHNIKE I INSTRUMENTI ISTRAŽIVANJA}

Sprovedeno mikroistraživanje je trebalo da pokaže da li promena analitičko-interpretativnog metoda, kao i primena adekvatnih metodičkih modela, utiču na motivaciju učenika i da li je procentualno veći broj učenika pročitao zadatu lektiru. Interesovalo nas je i da li se formirao pozitivan stav prema tekstu koji se obrađivao. Istraživanje je izvršeno na uzorku od jednog odeljenja IV razreda društveno-jezičkog smera u gimnaziji „Jovan Jovanović Zmaj“ u Novom Sadu (35 učenika, od kojih je u proseku nešto više od $80 \%$ bilo prisutno na nastavi). Istraživanje je trajalo tri časa tokom kojih je obrađena jedna nastavna jedinica, $\mathrm{u}$ periodu od 26. do 28. marta 2014. godine. Osnovna istraživačka tehnika je anketiranje, tj. evaluacioni list koji je anonimni, kao i evaluacioni list koji popunjava nastavnik, uz posmatranje i praćenje nastavnog procesa. Analiza rezultata je urađena deskriptivnom metodom.

Za potrebe istraživanja konstruisani su sledeći elementi ${ }^{5}$ :

- Posebne pripreme i aplikacije za izvođenje nastave,

- Evaluacioni list za učenike (anonimni) i

- Evaluacioni list za nastavnika.

\section{REZULTATI ISTRAŽIVANJA I NJIHOVA INTERPRETACIJA}

Nastavi je tokom istraživanja prisustvovao veliki broj učenika, uglavnom oko $80 \%$ razreda, koliko ih je i popunilo evaluacioni list (29 od 35 učenika).

5 Kompletne pripreme, uzorak formulara za učeničku evaluaciju, kao i kopija popunjene evaluacije nastavnika su date u prilozima na kraju teksta. 
Praćenjem nastavnog procesa uočeno je da je dijaloška forma nesmetano funkcionisala, učenici su bili aktivni, zainteresovani, i, čini se, priviknuti na ovakav metod. Uočeno je da su učenici informisani, većina je aktivno učestvovala u dijalogu, dajući odgovore ali i postavljajući pitanja. Nakon prvog časa, zainteresovani materijom, dodatno su se informisali o pojedinostima i na naredne časove došli unapred pripremljeni. Metod predavanja i analize su evaluacijom ocenili pozitivno, i to $59 \%$ se opredelilo za „odlično“, $17 \%$ za „veoma dobro“ i $24 \%$ za „dobro“. Visok procenat učenika je pročitao delo, što su potvrdili i rezultati evaluacije - svi učenici koji su prisustvovali nastavi, od kojih je 55\% pročitalo pre, $31 \%$ tokom, a $14 \%$ nakon časova obrade. Iako su utisci o romanu pre časova obrade bili uglavnom pozitivni (oko 80\%), ipak je veoma visok procenat učenika (čak 90\%) bio mišljenja da su nakon časova obrade bolje razumeli delo i osećaju se veštijim u čitanju slične literature. Više od polovine ispitanih učenika se izjasnilo pozitivno na pitanje da li planiraju da pročitaju još neko delo Mihaila Bulgakova - njih 60\%, $25 \%$ je odgovorilo neodređeno, a samo je $15 \%$ bilo nezainteresovano, dok se čak $85 \%$ ispitanih učenika izjasnilo pozitivno u nameri da pročitaju dela pisaca sličnih poetičkih odlika. Pojedini ispitanici su ostavili i komentar na evaluacionom listu. Navešćemo neke od njih:

Jako zanimljivo i drugačije.

Sviđa mi se što smo ovaj roman ovako obrađivali, na nekom boljem $i$ višem nivou.

Dopala mi se spona sa Biblijom i drugim delima. Vrlo me zainteresovala priča o Esenima i nameravam da malo dublje to istražim.

Predavanja su mi otvorila nove vidike na ovu temu i podstakla na razmišljanje.

Dopada mi se traženje spone $i$ sličnog sa romanima koje smo prethodno pročitali.

Otvorila se nova ideja i način tumačenja, radije ću čitati i razgovarati o tome.

Iako je uzorak na kojem je izvršeno istraživanje prilično mali, stoga i ima karakter mikroistraživanja, i uslovi se mogu smatrati gotovo idealnim (opremljen kabinet, izuzetno kolegijalan nastavnik, učenici koji imaju vidne čitalačke navike i kompetencije), ipak su rezultati i više nego zadovoljavajući. Stopostotnost pročitanosti dela, visoki procenti pozitivno ocenjenog metoda i pozitivnih odgovora na pitanja koja se tiču razumevanja teksta nakon nastave i zainteresovanosti za dalje bavljenje sličnim temama daju potvrdu hipoteze da izložena inovacija u nastavi rezultira povećanom motivacijom kod učenika. Uz to, budući da je anketa anonimna i ničim ne utiče na njihovu ocenu, osećali su se slobodnim da daju iskrene 
odgovore i napišu komentare, koji su izuzetno odobravajući. Tokom same nastave učenici su bili vidno intrigirani pojedinim pitanjima koja su otvorena, naročito u kontekstu dekonstrukcije biblijskih elemenata i problematizovanja Biblije uopšte kao knjige na kojoj počiva vera i civilizacija već dve hiljade godina, uspevši pritom da ostave po strani lična ubeđenja i verovanja i postave se objektivno i kritički u odnosu na informacije koje su dobili, jednako kao i na informacije koje već poseduju o tome.

Evaluacioni list konstruisan za nastavnika imao je za cilj da se dobije povratna informacija, kao i da se premosti određeni problem koji se javlja kod ovakve vrste istraživanja - da se sazna prethodni kontekst razreda. Uopšteno uzevši, evaluacija nastavnika je veoma pozitivna. Zaključak je da su učenici pročitali delo u većem broju nego što je to uobičajeno, da su samim tim bili bolje motivisani, mada im je i novi pristup diskusiju učinio zanimljivijom i intrigantnijom. Ovakav pristup delu je adekvatniji jer omogućava kompleksan pristup literaturi i bolju integraciju sa drugim predmetima, što je jedan od preduslova za poboljšanje kvaliteta nastave. Pored toga što je, kako kaže, u startu bilo teže jer ovaj metod pretpostavlja kompleksniju pripremu, sa druge strane je inspirativniji i interesantniji, predavač postaje motivisaniji i ta se energija prenosi i na učenike. Kao moguću kritiku i komentar nastavnik navodi napomenu kako je ovakav metod teško primeniti u uslovima koji su propisani postojećom normom i brojem učenika u razredu koji često premašuje trideset.

\section{ZAKLJUČAK}

Videli smo da motivacija učenika za čitanjem i aktivnim učešćem u nastavnom i misaonom procesu podjednako zavisi od mnogobrojnih faktora unutar i izvan učionice. Ako ličnost nastavnika, njegove afinitete i ličnu motivisanost i angažman uzmemo kao ključne za motivisanje učenika, u tom slučaju bi implementacija savremenih književnometodoloških tokova na nastavnu praksu bila najpodesnije rešenje za postizanje tog efekta jer savremeni pristupi tekstu otvaraju brojne mogućnosti u kreiranju nastave. Ovu tezu smo isprobali u praksi, konstruišući mikroistraživanje koje smo sproveli, i koje je obuhvatalo posmatranje i praćenje nastavnog procesa i popunjavanje evaluacionog listića od strane učenika i nastavnika. Hipoteza da su učenici srazmerno motivisaniji, aktivniji i da je broj onih koji su pročitali delo u porastu ukoliko je pristup tekstu inovativniji, što, na kraju, motiviše i samog nastavnika, u velikoj meri je potvrđena učeničkom evaluacijom.

Neki od pisanih i usmenih komentara učenika na poslednjem času obrade (sinteze): učenici smatraju da je tada bilo pravo vreme za čitanje; delo su daleko 
drugačije i bolje razumeli nakon predavanja, da ga letos nisu razumeli uopšte; učenici se slažu sa tim da je roman semiotički i da im bez znanja o tadašnjim okolnostima deluje nebulozno, ali bez ovih intertekstualnih i interkulturalnih povezivanja im deluje jednostrano; učenici imaju utisak da im se otvorilo potpuno novo polje gledanja na književnost, što je i dokaz njihove motivisanosti i ujedno i najveća potvrda hipoteze koja je ispitana ovim putem.

\section{PRILOZI}

Prilog 1:

Pripreme za izvođenje nastave:

- Prvi čas:

Škola: Gimnazija „Jovan Jovanović Zmaj“, Novi Sad

Razred: IV5

Datum: 26. IV 2014.

Vreme: 9:10h

Predmet: Srpski jezik i književnost

Tip časa: obrada (uvodni)

Nastavna jedinica: Mihail Afanasjevič Bulgakov „Majstor i Margarita“

Cilj časa:

I. Obrazovni:

2. Utvrđivanje i primena stečenih znanja o poetici postmoderne - metoda palimpsesta, transliterarnost, dekonstrukcija žanrova, uloga fantastike, odnos prema istoriji, literatura kao građa.

3. Lociranje Bulgakovljevog dela u rusku nacionalnu kao i svetsku istoriju književnosti, i upoznavanje sa njegovim životom i delom.

4. Uočavanje pozicije intelektualca u totalitarnom režimu.

II. Funkcionalni:

1. Povezivanje i sistematizacija znanja stečenih na časovima istorije, sociologije, filozofije i književnosti o odnosu pojedinca i društva, njihov međusobni uticaj, razvijanje i jačanje pojedinih represivnih i totalitarističkih ideja i sistema i pozicije umetnika u njima.

2. Uočavanje značaja umetnosti i umetnika kao glasnogovornika slobode u pojedinim društvenim uređenjima kroz istoriju, posebno u vreme i posle Oktobarske revolucije u Rusiji. 
3. Osposobljavanje učenika za formiranje kritičkog stava prema državnom i društvenom uređenju.

Nastavne metode: monološka, dijaloška, tekst metoda

Oblici rada: frontalni

Nastavna sredstva: laptop, projektor

Literatura:

Bulgakov, M. (2004). Majstor i Margarita. Beograd: Novosti.

Flaker, A. (1998). Bulgakovljev ,, Majstor i Margarita “. Zagreb: Liber.

Živković, D. (2001). Rečnik književnih termina. Banja Luka: Romanov.

Ilić, P. (1997). Srpski jezik i književnost u nastavnoj teoriji i praksi. Novi

Sad: Prometej.

Vremenska struktura časa:

1. Uvodni deo: 10 minuta

2. Glavni deo: 25 minuta

3. Završni deo: 10 minuta

\section{Uvodni deo}

Dijalogom se podsećamo na stečena znanja o periodu postmoderne - kom istorijskom periodu pripada, ko su predstavnici, šta su osnovne poetičke odlike (specifičan odnos prema istoriji, dokumentima, literaturi kao građi, originalnosti, pisanju i čitaocima, dekonstrukcija žanrova, mitova, stilova), koje su odlike postmodernističke fantastike, šta je autopoetika, šta je intertekstualnost, šta su citati i koja je njihova funkcija u književnom delu?

\section{Glavni deo}

Ukazivanje na pojedine ključne tačke iz piščevog života: lekar po vokaciji (Za koje još pisce lekare znamo? - Čehov, Zmaj, Lazarević) koji u određenom trenutku počinje da se zanima za literaturu, toliko da napušta svoj poziv radi nje, seli se u Moskvu ne bi li postao pisac po vokaciji; vremenske (ne)prilike u kojima živi i stvara - pokušaji da objavi dela, trenutak kada želi da emigrira koji rezultira stalnim angažmanom u režimu koji ga sankcioniše, ali samo donekle, ima za zadatak da kontekstualizuje genezu romana. U kom to istorijskom i književnoteorijskom periodu Bulgakov stvara? Diskusija o poziciji pisca i umetnika i umetnosti uopšte u totalitarnim režimima, uz osvrt na usvojeni pojam disidenta i nabrojavanje poznatih pisaca u toj poziciji. Zašto je državno i društveno uređenje bitno za stvaranje? Da li je i zašto umetnik, posebno pisac, glasnogovornik slobode, i šta je uopšte sloboda? Istaći odnos autora prema romanu Majstor i Margarita - vreme pisanja, geneza romana i razmišljanje o naslovima, bibliografija koju ostavlja kao slika odnosa prema pisanju i stvaranju koje je za vreme u kojem Bulgakov 
stvara i više nego vizionarsko. Naime, u periodu modernog evropskog romana Bulgakov piše jedan posve savremeni, „semiotički“ roman, koji se raslojava na bezbroj mogućih načina u zavisnosti od pozicije iz koje se čita i same književne kulture čitaoca. Budući da je pisan u jednom ironičnom, parodijskom kontekstu, ovaj roman se, poput Don Kihota, može čitati u više ključeva, što kombinujući sa uzrastom, erudicijom i vremenom u kome čitalac živi, sa svakim čitanjem menja kôd, poruku, značenje i interpretaciju, što objašnjava momenat u kojem je objavljen (sluh publike za ovakvo delo) i njegovu popularnost širom sveta.

\section{Završni deo}

Vraćanje na bibliografiju uz roman: tematski koje knjige dominiraju u naslovima? Koje bi teme bile ključne za razmatranje, odnosno, koja je tema/motiv/ književni mit dominantan u romanu? Sa kojim delima na prvi pogled (naslov) dovode u vezu ovaj roman? Najvažnije pitanje - da li je i zašto važno dovesti u vezu delo koje čitamo sa delima koja (ni)smo čitali? Gde uočavaju citate na samom početku čitanja i gde nas pisac njima usmerava i zašto?

- Drugi čas:

Škola: Gimnazija „Jovan Jovanović Zmaj“, Novi Sad

Razred: IV5

Datum: 27. IV 2014.

Vreme: 8:20h

Predmet: Srpski jezik i književnost

Tip časa: obrada (glavni)

Nastavna jedinica: Mihail Afanasjevič Bulgakov „Majstor i Margarita“

Cilj časa:

I Obrazovni:

1. Rezimiranje književnih dela kroz koja se kreće faustovski motiv u svrhu sistematičnijeg pogleda na književnu baštinu.

2. Sticanje uvida u povezanost istorijskog i sociološkog trenutka sa piščevim odabirom teme i upotrebom određenog književnog postupka.

3. Rasvetljavanje pojma arhetipa u književnosti, njegovog stvaranja, funkcije i metamorfoze.

II Funkcionalni:

1. Uočavanje i praćenje citata u tekstu, i mogućnosti za njihovo povezivanje i međusobnu reinterpretaciju. 
2. Osposobljavanje učenika za uviđanje različitih uglova i izmeštanje fokusa za analizu i interpretaciju književnog teksta.

3. Primena stečenih znanja iz društveno-humanističkih predmeta prilikom interpretacije književnog teksta.

Nastavne metode: monološka, dijaloška, tekst metoda

Oblici rada: frontalni

Nastavna sredstva: laptop, projektor

Literatura:

Bulgakov, M. (2004). Majstor i Margarita. Beograd: Novosti.

Flaker, A. (1998). Bulgakovljev „, Majstor i Margarita “. Zagreb: Liber.

Živković, D. (2001). Rečnik književnih termina. Banja Luka: Romanov.

Ilić, P. (1997). Srpski jezik i književnost u nastavnoj teoriji i praksi. Novi

Sad: Prometej.

Vremenska struktura časa:

1. Uvodni deo: 5 minuta

2. Glavni deo: 30 minuta

3. Završni deo: 10 minuta

1. Uvodni deo

Kratak osvrt na ključne tačke sa prethodnog časa - Bulgakovljev život i rad, okolnosti nastanka i objavljivanja romana Majstor i Margarita, do pomenute bibliografije koju nam pisac nudi i pitanja koja su sa tim u vezi bila postavljena, o čemu će se govoriti na glavnom delu časa u cilju rasvetljavanja aspekata iz kojih se pristupa interpretaciji.

\section{Glavni deo}

Vraćamo se pitanjima postavljenim na kraju prethodnog časa. Koje su im knjige/naslovi prva asocijacija kada vide naslov i moto romana? Gde uočavaju citate na samom početku čitanja i gde nas pisac njima usmerava i zašto? Da li ti naslovi postoje na spisku koji je pisac ostavio? Da li su im poznati naslovi knjiga, koji su im poznati i zašto/odakle? Sa tim u vezi, koje bi teme po njihovom mišljenju bile ključne za razmatranje, odnosno, koja je tema/motiv/književni mit dominantan u romanu? Najvažnije pitanje - da li je i zašto važno dovesti u vezu delo koje čitamo sa delima koja (ni)smo čitali? Da li nam intertekstualnost olakšava ili otežava recepciju i interpretaciju dela i zašto?

Ustanovivši da je dominantan književni motiv prisutan u delu faustovski, pristupamo strukturalnoj analizi romana interpretirajući ga iz ugla glavnog motiva i uočavajući sporedne koji se nadovezuju. Na prvi pogled je jasno prisustvo romana unutar romana, koji mimo toga ima paralelni sklop. Ostavićemo na tre- 
nutak po strani umetnuti roman i posmatrati osnovni sklop. Nabrajanjem likova, njihovih imena, pojava, zanimanja i funkcija u delu uočava se veza sa faustovskim motivom: Voland, profesor crne magije, koji u pratnji ima družinu među kojom i čovekolikog crnog mačka, kao paralela Mefistofelesu; Margarita, koja pored imena, ima i karakternih i sudbinskih sličnosti sa Faustovom Margaretom, i na kraju Majstor, bezimeni umetnik koji stvara delo koje pokušava da uništi i zbog kojeg završava u duševnoj bolnici, koji posredstvom Margaritine ljubavi uspeva da dobije slobodu i spokoj, ima najviše sličnosti sa likom samog Fausta utoliko što oba predstavljaju arhetip čoveka sumnje, i onoga koji sebi pripisuje Tvoračke moći, što ih skupo košta. Ovaj aspekt romana je pisan u fantastičkom ključu, i to fantastikom kafkijanskog tipa, gde nailazimo na jednu posebnu atmosferu koju Bulgakov vešto gradi, i koja balansira na finoj, tankoj niti između čiste fantastike i satire, odnosno apsurda i aluzije. Priča o umetniku ima i naličje - epizode o Sataninim smicalicama u Moskvi su direktna satira na račun ne toliko samog totalitarnog režima, koliko na stanje svesti i ponašanje građana unutar istog, jednako onih koji su ga krojili kao i onih koji su se u njemu zatekli. Kažem naličje stoga što je osnovna ravan koju vidimo opsesivna tema (post)modernog romana, a to je lik umetnika, stvaraoca, odnosno pisca i samo stvaranje, čija je pozadina/naličje sudbina takvog lika u određenim društvenim/životnim okolnostima.

\section{Završni deo}

Za kraj rezimirati i zabeležiti pobrojane motive: faustovski kompleks motiva kao dominantan (čovek sumnje, stvaranje, pakt sa đavolom), društvo i pojedinci pod totalitarnim režimom, fantastični motivi (veštičarenje, Valpurgijska noć, fantastika prostora i vremena) itd. Postaviti pitanja kojima će se otvoriti naredni čas, a to su pitanja motiva i citata koji se još mogu videti i izdvojiti kao referentni, kao i dekonstrukcije koje Bulgakov vrši. Pored već spomenute dekonstrukcije faustovskog mita, ključna je dekonstrukcija Novog zaveta, što nas vraća na umetnuti roman kojim ćemo se baviti na narednom času.

- Treći čas:

Škola: Gimnazija „Jovan Jovanović Zmaj“, Novi Sad

Razred: IV5

Datum: 27. IV 2014.

Vreme: 9:10h

Predmet: Srpski jezik i književnost

Tip časa: obrada (završni)

Nastavna jedinica: Mihail Afanasjevič Bulgakov „Majstor i Margarita“

Cilj časa: 
I Obrazovni:

1. Rasvetljavanje pojma arhetipa u književnosti, njegovog stvaranja, funkcije i metamorfoze.

2. Upoznavanje sa pojmom apokrifnog jevanđelja i osvrt na istorijski razvoj hrišćanstva kao religije i njegovog značaja za civilizaciju u kojoj živimo danas i njenu umetnost.

3. Upoznavanje sa pojmovima semiotika i semiotički roman.

II Funkcionalni:

1. Uočavanje i praćenje citata u tekstu, i mogućnosti za njihovo povezivanje i međusobnu reinterpretaciju.

2. Osposobljavanje učenika za uviđanje različitih uglova i izmeštanje fokusa za analizu i interpretaciju književnog teksta.

3. Primena stečenih znanja iz društveno-humanističkih predmeta prilikom interpretacije književnog teksta.

Nastavne metode: monološka, dijaloška, tekst i demonstrativna metoda

Oblici rada: frontalni

Nastavna sredstva: laptop, projektor, internet konekcija ili DVD snimak dokumentarnog filma

Literatura:

Bulgakov, M. (2004). Majstor i Margarita. Beograd: Novosti.

Flaker, A. (1998). Bulgakovljev „, Majstor i Margarita“. Zagreb: Liber.

Živković, D. (2001). Rečnik književnih termina. Banja Luka: Romanov.

Ilić, P. (1997). Srpski jezik i književnost u nastavnoj teoriji i praksi. Novi Sad: Prometej.

The Real Da Vinci Code (Istiniti Da Vinčijev kod) Pristupljeno 28. 3. 2014. URL: https://www.youtube.com/watch?v=xpaADUxFNuA. min. od 33:30 do 35:24 i od 1:23:19 do 1:29:18

Riddles Of The Bible - Dead Sea Scrolls (Zagonetke Biblije - Svici s Mrtvog mora) Pristupljeno 28. 3. 2014.

URL: https://www.youtube.com/watch?v=byF04CYuSFM. min. od 45:17 do 47:03

Vremenska struktura časa:

1. Uvodni deo: 5 minuta

2. Glavni deo: 30 minuta

3. Završni deo: 10 minuta 
1. Uvodni deo

Kratak osvrt na ključne tačke sa prethodnog časa - struktura romana, dominantni motivi, fantastika i dekonstrukcija.

\section{Glavni deo}

Koje su linije dekonstrukcije uočljive u romanu? U prvom planu je dekonstruisana sama forma romana (postoji roman unutar romana). Postavlja se pitanje teme tog umetnutog romana (Roman o Petom prokuratoru Judeje), što nas vodi zaključku da pisac dekonstruiše Novi zavet pišući svojevrsno lično Jevanđelje, ali samo po temi, ne i po formi. Postavlja se pitanje izbora teme za umetnuti roman, i zašto Bulgakov „pisca“ romana, tj. Majstora zbog toga stavlja u duševnu bolnicu? Šta nam to govori o piščevom stavu prema stvaranju i da li je to kritika režima koji sputava i sankcioniše određeni način mišljenja? Ukoliko je ima u čemu se ona ogleda? Kakav je odnos staljinističkog režima prema religiji? Jedan od najčuvenijih Marksovih citata danas je da je religija opijum za mase. Kako to učenici razumeju i tumače? Kako umetnost kroz vekove gleda na Bibliju i kakav je njen položaj u postmodernoj (još uvek je najprodavanija knjiga svih vremena, a drugi najprodavaniji roman s kraja XX veka se bavi upravo Biblijom - Braunov Da Vinčijev kod)? Pušta se insert iz dokumentarnog filma čija tema su apokrifna jevanđelja poznata kao Svici s Mrtvog mora, potom se izlažu činjenice o nastanku kanona Novog zaveta, odnosno crkvenih sabora na kojima su usvojena četiri jevanđelja koja danas čine kanon. Podstiču se da iznesu svoje mišljenje o predočenim informacijama. Na koji način bi oni povezali sadržaj i intenciju Bulgakovljevog romana o Pontiju Pilatu u kontekstu „raskrinkavanja“" Biblije kao svetog teksta danas? Povodom rekonstrukcije pomenutih svitaka i prevođenja sa jezika na kojima su pisani, uvodi se termin semiotike kao nauke koja se bavi proučavanjem znakova. Važno jer se semiotika kao nauka formira približno u vreme kada su pomenuti tekstovi otkriveni, kada se menja paradigma lingvističkih i književnoteorijskih proučavanja, gde pomenute nauke uz semiotiku kreću ka sumiranju u kulturološke studije, jer se sve više primećuje da je nemoguće pojedine književne fenomene posmatrati izolovano u odnosu na sociološke, istorijske, kulturne, lingvističke, političke, i sve ostale prilike u kojima su nastali, ali i u kojima se proučavaju. Semiotika, dakle, proučava znakove i komunikaciju, i jedan od vodećih naučnika iz tog polja tada i danas je svakako Umberto Eko, čiji se roman Ime ruže može okarakterisati kao semiotički, znakovni, upućujući, kodirani roman koji se sastoji od mnoštva šifrovanih poruka čiji se ključevi kriju u samom tekstu i koji zahtevaju vrlo pažljivog čitaoca-eruditu. Da li je, po njihovom mišljenju, Majstor i Margarita semiotički roman, i zašto? 
3. Završni deo

Sinteza komentara i utisaka - koji su novi pojmovi usvojeni, gde se mogu primeniti, koliko je roman zahtevan za čitanje i koje su njihove impresije o romanu pre i nakon njegove analize.

\section{Prilog 2:}

\section{EVALUACIONI LISTIĆ}

Kako ocenjujete predavanje o „Majstoru i Margariti“ M. A. Bulgakova (zaokruži)? odlično veoma dobro dobro loše veoma loše Da li ste pročitali delo pre, u toku časova obrade ili posle analize na času? pre časa tokom časova obrade posle časa Kakvi su vaši utisci o romanu bili pre časova obrade? pretežno pozitivni pretežno negativni Da li vam se čini da ste delo drugačije razumeli posle časova obrade? da ne

Da li vam se čini da ste nakon ovih časova veštiji u čitanju slične literature? da ne

Da li želite/planirate da pročitate još neko delo Mihaila Bulgakova i koje?

Da li želite/planirate da potražite i pročitate dela pisaca sličnih poetskih odlika?

Komentar:

Prilog 3:

Kopija popunjenog evaluacionog lista predavača: 
МЕТОДИЧКИ ВИДИЦИ

ЕВАЛУАЦИОНИ ЛИСТИЋ

1. Какви су Ваши утисци након одржаних часова?

одлични

веома добри

добри

лоши

веома лоши

Cboka Hobeuta graxuroch novosmany yuxaka.

2. Да ли Вам се чини да су ученици прочитали дело у већем или мањем броју него што је уобичајено?

Yuesnuss of unormione seno y beken onory neiv unv se yoduragito.

3. Да ли Вам се чини да су ученици били више или мање мотивисани за учешће на часу него што је уобичајено? Образложите одговор.

Marn ce ga cy ynestuza dum dope nounlencoqu. Tnlo zañ mus di duso lenue

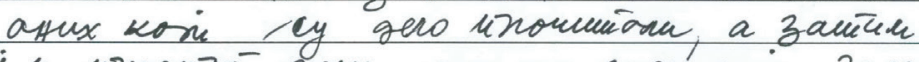

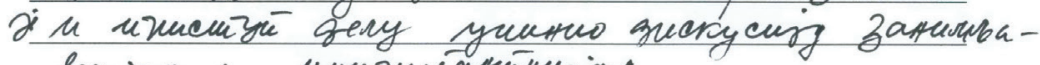

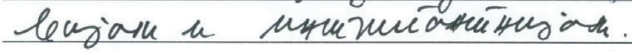

4. Да ли сматрате да је овакав модел наставе адекватнији од уобичајеног и зашто?

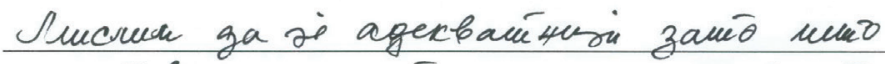

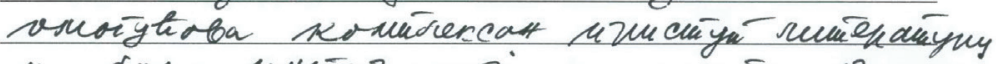

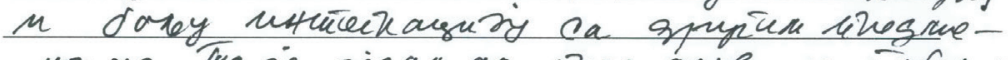

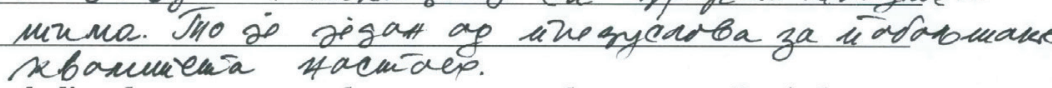

5. Како бисте оценили опробани метод и да ли бисте рекли да Вам је било теже или лакше да предајете оваквим методом и зашто?

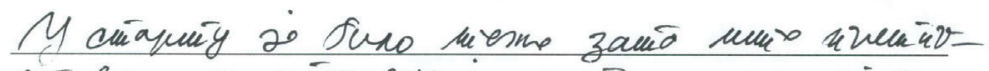

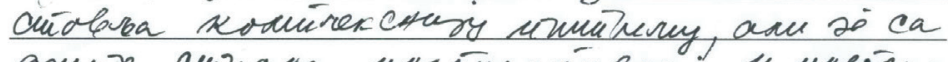

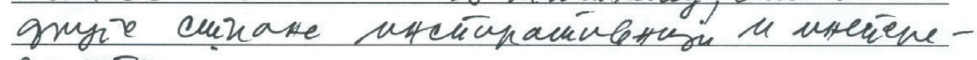
carraturin.

73 

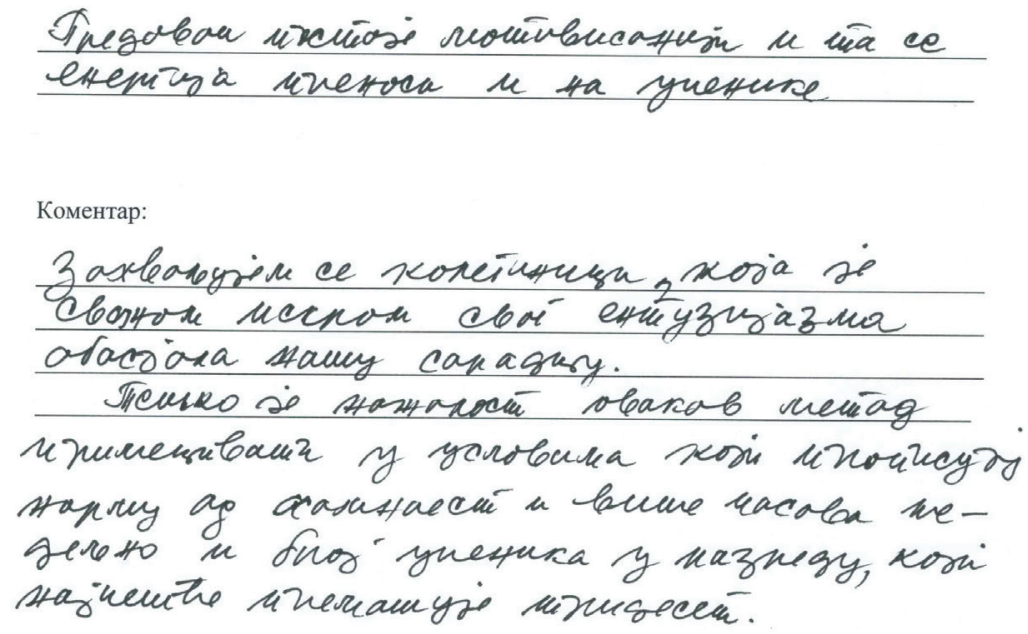

\section{LITERATURA}

Bahtin, M. (1989). O romanu. Beograd: Nolit. Bulgakov, M. (2004). Majstor i Margarita. Beograd: Novosti.

Eko, U. (2011). Kazati gotovo istu stvar. Beograd: Paidea.

Flaker, A. (1988). Bulgakovljev ,, Majstor i Margarita “. Zagreb: Liber.

Gage - Berliner (1998). Educational Psychology. Boston: Houghton Mifflin Company.

Ilić, P. (1997). Srpski jezik i književnost u nastavnoj teoriji i praksi. Novi Sad: Prometej.

Ilić, P., Gajić, O., Maljković M. (2008). Kriza čitanja. Novi Sad: Gradska biblioteka; Beograd: Nova škola.

Juvan, M. (2013). Intertekstualnost. Novi Sad: Akademska knjiga.

Lotman, J. (2004). Semiosfera: u svetu mišljenja. Novi Sad: Svetovi.

Maslow, A. (1954). Motivation and personality. New York: Harper.

Milanov, A. (2013). "Inovativnost u nastavnom procesu kao put ka motivisanom učeniku“, u Zbornik sa 7. Međunarodne naučne konferencije Motivacijaodržavanje pažnje učenika, ur. Czékus G. (Subotica: Učiteljski fakultet na mađarskom nastavnom jeziku): 475-483. 
Živković, D. (2001). Rečnik književnih termina. Banja Luka: Romanov. Dokumentarni filmovi:

The Real Da Vinci Code (Istiniti Da Vinčijev kod) Pristupljeno 28. 3. 2014. URL: https://www.youtube.com/watch? $v=x p a A D U x F N u A$. min. od 33:30 do 35:24 i od 1:23:19 do 1:29:18.

Riddles Of The Bible - Dead Sea Scrolls (Zagonetke Biblije - Svici s Mrtvog mora) Pristupljeno 28. 3. 2014. URL: https://www.youtube.com/watch? $\mathrm{v}=$ byF04CYuSFM. min. od 45:17 do 47:03.

\section{Albina M. Milanov}

\section{BULGAKOV IN THE TEACHING PRACTICE}

\section{Summary}

This paper presents the results of a research conducted in „Jovan Jovanović Zmaj“ Grammar school in March 2014 with a sample of 35 students. The experimental procedure consisted of specially designed teaching methods and approaches, as well as the evaluation papers, with the aim of confirming the hypothesis that students' motivation increases as a result of intertextuality used as a method of analysis and as a basis for the implementation of lessons. We know that students' motivation for reading and active participation in the process learning and thinking depends on many factors, both inside and outside the classroom. If a teacher's personality, his or her preferences, and personal motivation and engagement are taken as the key factors in motivating students, applying ideas of modern literary theory in the teaching process is the most appropriate solution to achieve that, since modern approaches in text analysis open up many possibilities in designing classes. We tried to test this theory in practice by constructing a micro-study, which included the observations and monitoring of the teaching process, as well as student and teacher evaluation forms. The hypothesis was that students are generally more motivated, more active in participation, and the number of those who read the book is proportionally on the rise if the approach to the text is more innovative, which ultimately motivates the teachers themselves. This was clearly confirmed in the students' evaluation results. Some of the written and oral comments made by students in the final lesson (the synthesis) were that they think that this was the right time to read the novel, because they understood it quite differently after the lecture. They also agreed that "Master and Margarita" is a semiotic novel, and that they had the impression that they opened up a whole new field of looking at literature. This is proof of their increasing motivation, and also the greatest confirmation of the hypothesis that was tested.

Key words: intertextuality, research, motivation, teaching. 